\title{
Penerapan Assosiation Rule Untuk Mendukung Sistem Pencapaian Target Pajak Pendapatan Kabupaten Deli Serdang
}

\author{
Muhammad Eka ${ }^{*}$, Rara Astili Siregar ${ }^{2}$ \\ Universitas Nahdlatul Ulama Sumatera Utara \\ Jl. Brigjend H. A.Manaf Lubis / Gaperta Ujung No.2 Medan, Telp : 061 - 80026202 \\ muhammadeka@yahoo.com
}

\begin{abstract}
Deli Serdang Regency has a complete and unique topography because there are coastal areas, lowlands and mountainous highlands with an area of 2,497.72 Ha consisting of 22 sub-districts, 380 villages and 14 villages. The main potential of the Deli Serdang regency are agriculture, smallholder plantations, large plantations, fisheries, aquaculture, livestock, industry, trade and tourism. Based on this big potential, Deli Serdang District Region has a large potential income tax. Planning and regional income tax management system of Deli Serdang Regency are carried out at the Regional Revenue Department of Deli Serdang Regency. Based on achievement data of tax revenue which is posted on Regional Deliberation Separtment of Deli Serdang Regency website, rate of regional income is still slow. The target line graph and the realization of regional revenues indicate that the targets have to be achieved are still far, because until June 2017 achievement only Rp. 56,950,403,904.02, - while the target to the end of December 2017 is Rp. 484,520,000,000. To achieve the annual target as expected need a strategy. Association analysis is also known as one of the data mining techniques basis of various other mining data techniques. By using the Apriori Algorithm, an analysis of the obstacles in achieving targets can be done to find interesting rules that are useful in supporting the system of achieving local tax targets. The implementation of Association Rule to support the achievement of the tax target is expected to help the process of achieving the target of regional income tax, especially in the Regional Revenue Department of Deli Serdang Regency.
\end{abstract}

Keywords: Data Mining, Association Rule, Apriori

\begin{abstract}
Abstrak
Wilayah Kabupaten Deli Serdang memiliki topografi yang lengkap dan unik karena didalamnya terdapat daerah pantai, dataran rendah dan dataran tinggi pegunungan dengan luas $\pm 2.497 .72 \mathrm{Ha}$ terdiri dari 22 kecamatan, 380 desa dan 14 kelurahan. Untuk potensi utama dari wilayah Kabupaten Deli serdang sendiri antara lain : pertanian, perkebunan rakyat, perkebunan besar, perikanan, pertambakan, peternakan, industri, perdagangan dan pariwisata. Berdasarkan potensi yang sangat besar tersebut maka Wilayah Kabupaten Deli Serdang memiliki potensi pajak pendapatan yang besar pula. Perencanaan maupun sistem pengelolaan pajak pendapatan daerah Kabupaten Deli Serdang di lakukan di Badan Pendapatan Daerah Kabupaten Deli Serdang. Berdasarkan data pencapaian pendapatan pajak yang di muat di laman situs Badan Pendapatan Daerah Kabupaten Deli Serdang terlihat masih lambatnya laju pendapatan daerah. Grafik garis target dan realisasi pendapatan daerah menunjukkan masih jauhnnya target yang harus di capai, karena sampai dengan bulan juni 2017 realisasi yang bisa dicapai sebesar Rp. 56.950.403.904.02,- sedangkan target yang harus dicapai sampai dengan akhir desember 2017 sebesar Rp. 484.520.000.000,-. Untuk itu perlu dilakukan strategi pencapaian target untuk mencapai target tahunan sesuai yang di harapkan. Analisis asosiasi dikenal juga sebagai salah satu teknik data mining yang menjadi dasar dari berbagai teknikdata mining lainnya. Dengan menggunakan Algoritma Apriori, analisis kendala dalam pencapaian target dapat dilakukan untuk mencari rule interesting yang berguna dalam mendukung sistem pencapaian target pajak daerah. Penerapan Assosiation Rule untuk untuk mendukung pencapaian target pajak diharapkan dapat membantu proses
\end{abstract}


pencapaian target pajak pendapatan daerah khususnya di Badan Pendapatan Daerah Kabupaten Deli Serdang.

\section{Kata kunci :Data Mining,Assosiation Rule, Apriori}

\section{PENDAHULUAN}

Kabupaten Deli Serdang memiliki potensi yang berbeda serta jumlah wajib pajak yang berbeda pula. Dengan demikian maka data yang tersimpan pun akan bertambah setiap harinya, terutama data penerimaan atau pembayaran pajak pendapatan daerah. Dari besarnya jumlah data penerimaan atau pembayaran pajak pendapatan daerah tersebut pastinya selalu ada data wajib pajak yang juga masih belum melakukan pembayaran pajak secara sadar dan rutin tepat waktu, dan jumlahnya juga cukup besar. Hal ini membuat pencapaian target pajak pendapatan daerah sulit dicapai, dan berdampak pada percepatan pertumbuhan infrastruktur maupun pembangunan daerah. Banyak faktor yang mempengaruhi tidak tercapainya target pajak dikarenakan keterlambatan maupun wajib pajak yang tidak mau membayar pajak tepat waktu.

Faktor yang mempengaruhi tidak tercapainya target pajak pendapatan daerah diantaranya seperti database yang tidak akurat, sistem penagihan, dan sumber daya manusia yang dimiliki Badan Pendapatan Daerah itu sendiri. Sedangkan di masyarakat faktor yang mempengaruhi tidak tercapainya target pajak pendapatan daerah diantaranya ekonomi lemah, tingkat pengangguran yang tinggi, desa tertinggal serta kurangnya sosialisasi dan kesadaran akan pentingnya membayar pajak. Dengan bantuan software Data mining untuk penggalian data penyebab ketidakcapain target pajak tahunan diharapkan akan mampu membantu sistem pencapain target pajak pendapatan di Badan Pendapatan Daerah Kabupaten Deli Serdang. Teknik penggalian data yang di lakukan dengan menggunakan algoritma Apriori.

\section{METODOLOGI PENELITIAN}

Analisis asosiasi dikenal juga sebagai salah satu teknik data mining yang menjadi dasar dari berbagai teknik data mining lainnya.Apriori adalah suatu algoritma yang sudah sangat dikenal dalam melakukan pencarian frequent itemset dengan menggunakan teknik association rule. Pada algoritma Apriori untuk menentukan kandidat-kandidat yang mungkin muncul dengan cara memperhatikan minimum support.

Sistem informasi yang digunakan di badan pendapatan daerah kabupaten Deli Serdang merupakan kunci keberhasilan dalam pelayanan pajak daerah kabupaten Deli Serdang. Artinya setiap laporan data transaksi pencapaian maupun pelaporan target pajak dilakukan menggunakan sistem komputerisasi. Dalam penelitian ini data yang diambil untuk mengukur seajauh mana kinerja pencapaian target pajak adalah data yang berasal dari database kantor Badan Pendapatan Daerah Kabupaten Deli Serdang, 
ditambah data yang berasal dari hasil wawancara langsung di lapangan kepada wajib pajak dan petugas pengutip pajak.

Ada banyak factor yang mempengaruhi keberhasilan pemungutan pajak sesuai target yang ditetapkan dilihat dari sudut pandang ilmu manajemen. Beberapa faktor tersebut antara lain : Manajemen Sumber Daya Manusia ( Tingkat keaktifan pegawai dalm melakukan pemungutan pajak, Tingkat kesadaran wajib pajak), Tingkat pertumbahan Ekonomi. Berikut tabel kegiatan yang dilakukan untuk mencapai target pajak antara lain: Pajak Hotel, Pajak Hiburan, Pajak Reklame dan Pajak Restoran yang dilakukan dari bulan maret sampai mei 2018.

\begin{tabular}{|c|c|c|}
\hline & \multicolumn{2}{|r|}{ Tabel 1. Data Kegiatan } \\
\hline No & Tanggal & Kegiatan \\
\hline \multirow[t]{2}{*}{1} & \multirow[t]{2}{*}{$1 \mathrm{~s} / \mathrm{d} 2$ maret 2018} & $\begin{array}{l}\text { Kantor Dinas mengeluarkan surat keterangan ke } \\
\text { KUPTD Wajib Pajak yang sudah jatuh tempo } \\
\text { maupun yang baru }\end{array}$ \\
\hline & & Memberikan surat pemberitahuan penunggak pajak \\
\hline \multirow{4}{*}{2} & \multirow{4}{*}{$5 \mathrm{~s} / \mathrm{d} 9$ maret 2018} & Koordinasi ke vendor untuk pajak reklame \\
\hline & & Sosialisasi ke wajib pajak reklame \\
\hline & & $\begin{array}{l}\text { Memonitor laporan bulanan ke wajib pajak untuk } \\
\text { pajak Perhotelan }\end{array}$ \\
\hline & & $\begin{array}{l}\text { Memonitor laporan bulanan ke WP untuk pajak } \\
\text { Restoran }\end{array}$ \\
\hline \multirow{4}{*}{3} & \multirow{4}{*}{$12 \mathrm{~s} / \mathrm{d} 16$ maret 2018} & $\begin{array}{l}\text { Memverifikasi ketidak cocokan data di kantor dinas } \\
\text { dan data dilapangan }\end{array}$ \\
\hline & & $\begin{array}{l}\text { Pengawasan langsung di lokasi usaha WP jika } \\
\text { terdapat ketidak sesuaian laporan dari data di } \\
\text { lokasi }\end{array}$ \\
\hline & & $\begin{array}{l}\text { Kegiatan dilakukan oleh } 3 \text { PNS dan } 6 \text { Pegawai } \\
\text { tidaktetap }\end{array}$ \\
\hline & & Tingkat kesadaran masyarakat (75\%) \\
\hline \multirow{5}{*}{4} & \multirow{5}{*}{19 s/d 23 maret 2018} & koordinasi ke vendor untuk pajak reklame \\
\hline & & Sosialisasi ke wajib pajak reklame \\
\hline & & $\begin{array}{l}\text { Memonitor laporan bulanan ke wajib pajak untuk } \\
\text { pajak Perhotelan }\end{array}$ \\
\hline & & $\begin{array}{l}\text { Memonitor laporan bulanan ke WP untuk pajak } \\
\text { Restoran }\end{array}$ \\
\hline & & $\begin{array}{l}\text { Memverifikasi ketidak cocokan data di kantor dinas } \\
\text { dan data dilapangan }\end{array}$ \\
\hline \multirow{5}{*}{5} & \multirow{5}{*}{$26 \mathrm{~s} / \mathrm{d} 30$ maret 2018} & $\begin{array}{l}\text { Pengawasan langsung di lokasi usaha WP jika } \\
\text { terdapat ketidak sesuaian laporan dari data di } \\
\text { lokasi }\end{array}$ \\
\hline & & $\begin{array}{l}\text { kegiatan dilakukan oleh } 51 \text { orang PNS dan } 121 \\
\text { orang Pegawai tidak tetap }\end{array}$ \\
\hline & & Rekapitulasi absensi (95\%) \\
\hline & & Tingkat kesadaran masyarakat (70\%) \\
\hline & & Rapat Evaluasi PAD \\
\hline \multirow{3}{*}{6} & \multirow{3}{*}{2 s/d 6 April 2018} & Memberikan surat pemberitahuan penunggak pajak \\
\hline & & Sosialisasi ke wajib pajak reklame \\
\hline & & $\begin{array}{l}\text { Memonitor laporan bulanan ke wajib pajak untuk } \\
\text { pajak Perhotelan }\end{array}$ \\
\hline 7 & 9 s/d 13 April 2018 & Memonitor laporan bulanan ke WP untuk pajak \\
\hline
\end{tabular}

Penerapan assosiation rule pada pencapaian target pajak (Muhammad Eka)|181 
Jurnal Sains Komputer \& Informatika (J-SAKTI)

Volume (2) No.2 September 2018, pp. 179-190

ISSN:2548-9771/EISSN:2549-7200

http://tunasbangsa.ac.id/ejurnal/index.php/jsakti

\begin{tabular}{|c|c|c|}
\hline No & Tanggal & Kegiatan \\
\hline & & Restoran \\
\hline & & $\begin{array}{l}\text { Kegiatan dilakukan oleh } 51 \text { orang PNS dan } 121 \\
\text { orang Pegawai tidak tetap }\end{array}$ \\
\hline & & Tingkat kesadaran masyarakat (65\%) \\
\hline \multirow{5}{*}{8} & \multirow{5}{*}{16 s/d 20 April 2018} & $\begin{array}{l}\text { Memonitor laporan bulanan ke wajib pajak untuk } \\
\text { pajak Perhotelan }\end{array}$ \\
\hline & & $\begin{array}{l}\text { Memonitor laporan bulanan ke WP untuk pajak } \\
\text { Restoran }\end{array}$ \\
\hline & & $\begin{array}{l}\text { Membuat surat peringatan } 1 \text { sampai } 3 \text { ke Wajib } \\
\text { Pajak yang membandel }\end{array}$ \\
\hline & & $\begin{array}{l}\text { Bekerjasama dengan Satpol PP menindak wajib } \\
\text { pajak yang tidak memiliki kesadaran setelah } \\
\text { meendapat SP3 }\end{array}$ \\
\hline & & $\begin{array}{l}\text { Memverifikasi ketidak cocokan data di kantor dinas } \\
\text { dan data dilapangan }\end{array}$ \\
\hline \multirow{4}{*}{9} & \multirow{4}{*}{23 s/d 30 April 2018} & $\begin{array}{l}\text { Pengawasan langsung di lokasi usaha WP jika } \\
\text { terdapat ketidak sesuaian laporan dari data di } \\
\text { lokasi }\end{array}$ \\
\hline & & $\begin{array}{l}\begin{array}{l}\text { Kegiatan dilakukan oleh } 51 \text { orang PNS dan } 121 \\
\text { orang Pegawai tidak tetap }\end{array} \\
\end{array}$ \\
\hline & & Rekapitulasi absensi (95\%) \\
\hline & & Tingkat kesadaran masyarakat (75\%) \\
\hline \multirow{6}{*}{10} & \multirow{6}{*}{1 s/d 4 Mei 2018} & Memberikan surat pemberitahuan penunggak pajak \\
\hline & & Sosialisasi ke wajib pajak reklame \\
\hline & & $\begin{array}{l}\text { Memonitor laporan bulanan ke WP untuk pajak } \\
\text { Restoran }\end{array}$ \\
\hline & & $\begin{array}{l}\text { Membuat surat peringatan } 1 \text { sampai } 3 \text { ke Wajib } \\
\text { Pajak yang membandel }\end{array}$ \\
\hline & & $\begin{array}{l}\text { Bekerjasama dengan Satpol PP menindak wajib } \\
\text { pajak yang tidak memiliki kesadaran setelah } \\
\text { meendapat SP3 }\end{array}$ \\
\hline & & $\begin{array}{l}\text { Memverifikasi ketidak cocokan data di kantor dinas } \\
\text { dan data dilapangan }\end{array}$ \\
\hline \multirow{3}{*}{11} & \multirow{3}{*}{7 s/d 11 Mei 2018} & $\begin{array}{l}\text { Pengawasan langsung di lokasi usaha WP jika } \\
\text { terdapat ketidak sesuaian laporan dari data di } \\
\text { lokasi }\end{array}$ \\
\hline & & $\begin{array}{l}\text { Kegiatan dilakukan oleh } 51 \text { orang PNS dan } 121 \\
\text { orang Pegawai tidak tetap }\end{array}$ \\
\hline & & Tingkat kesadaran masyarakat (70\%) \\
\hline \multirow{4}{*}{12} & \multirow{4}{*}{14 s/d 18 Mei 2018} & $\begin{array}{lcc}\begin{array}{l}\text { Pegawai atau Petugas mengantarkan surat } \\
\text { keterlambatan ke wajib pajak }\end{array} & \\
\end{array}$ \\
\hline & & koordinasi ke vendor untuk pajak reklame \\
\hline & & sosialisasi ke wajib pajak reklame \\
\hline & & $\begin{array}{l}\text { Memonitor laporan bulanan ke wajib pajak untuk } \\
\text { pajak Perhotelan }\end{array}$ \\
\hline \multirow{2}{*}{13} & \multirow{2}{*}{21 s/d 25 Mei 2018} & $\begin{array}{l}\text { Memonitor laporan bulanan ke WP untuk pajak } \\
\text { Restoran }\end{array}$ \\
\hline & & $\begin{array}{l}\text { Memverifikasi ketidak cocokan data di kantor dinas } \\
\text { dan data dilapangan }\end{array}$ \\
\hline 14 & 28 s/d 31 Mei 2018 & $\begin{array}{l}\text { Pengawasan langsung di lokasi usaha WP jika } \\
\text { terdapat ketidak sesuaian laporan dari data di } \\
\text { lokasi }\end{array}$ \\
\hline
\end{tabular}

Penerapan assosiation rule pada pencapaian target pajak (Muhammad Eka) | 182 
Jurnal Sains Komputer \& Informatika (J-SAKTI)

Volume (2) No.2 September 2018, pp. 179-190

ISSN:2548-9771/EISSN:2549-7200

http://tunasbangsa.ac.id/ejurnal/index.php/jsakti

\begin{tabular}{|l|l|l|}
\hline No & Tanggal & \multicolumn{1}{c|}{ Kegiatan } \\
\hline \multirow{2}{*}{} & & $\begin{array}{l}\text { Kegiatan dilakukan oleh 51 orang PNS dan 121 } \\
\text { orang Pegawai tidak tetap }\end{array}$ \\
\cline { 3 - 3 } & & Rekapitulasi absensi (95\%) \\
\cline { 3 - 3 } & & Tingkat kesadaran masyarakat (75\%) \\
\hline
\end{tabular}

Pola hubungan yang dibentuk dari kegaiatan yang dilakukan adalah dimulai dari pembentukan pola kombinasi satu itemset, dari pola kombinasi satu itemsets, terbentuk lah pola kombinasi dua itemsets, dari kombinasi pola kombinasi dua itemsets terbentuk lagi pola kombinasi tiga itemsets. Pembentukan pola kombinasi didasarkan pada nilai support minimal, Jika nilai support minimal terpenuhi dan pola kombinasi itemsets yang ada lebih dari pada satu pola kombinasi, maka pola kombinasi itemsets yang berikutnya bisa dibentuk. Setelah selesai pembuatan pola maka langkah selanjutnya pembentuk rules association, rules yang akan dihasilkan dibentuk dari pola kombinasi itemsets yang memenuhi support minimal. Gambar 4.2 merupakan flowchart algorima apriori sebagai berikut:

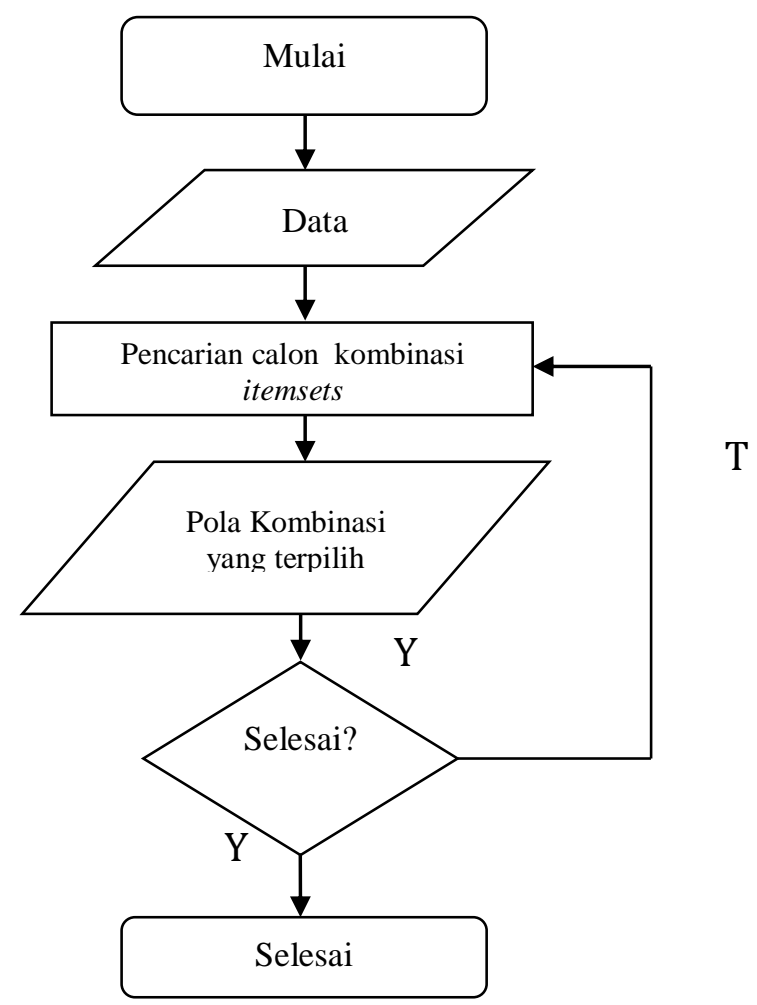

Gambar 1. Flowchart Algoritma Apriori

\subsection{Analisa Pola Frekuensi Tinggi}

Sebelum dilakukan pencarian pola dari data diatas terlebih dulu, dicari semua jenis kegiatan yang dilakukan atau item yang dilakukan seperti pada tabel diatas sekaligus menentukan support per kegiatan item yang dilakukan untuk mencapai target pajak, dimana tahap ini mencari kombinasi kegiatan para pegawai maupun pegawai non PNS atau item yang memenuhi syarat 
minimum dari nilai support dalam database, nilai support sebuah item diperoleh dengan rumus berikut:

$$
\operatorname{Support}(A)=\frac{\text { Jumlah_transaksi_yang_mengandung_A }}{\sum \text { Transaksi }}
$$

Sedangkan nilai support dari dua item diperoleh dengan rumus berikut:

$$
\begin{aligned}
& \operatorname{Support}(A, B)=P(A \cap B) \\
& \operatorname{Support}(A, B)=\frac{\sum \text { Transaksi_yang _ mengandung _ } A_{-} \text {dan_B }}{\sum \text { Transaksi }}
\end{aligned}
$$

Berikut merupakan jenis kegiatan yang dilakukan atau item yang dilakukan untuk mencapai target pajak perkecamatan di kabupaten deli serdang. Bentuk data satu item, yang terdiri atas attribute item sebagai nama item jenis semua kegiatan, support yaitu jumlah setiap item yang ada disemua kegiatan, sedangkan support (\%) adalah presentasi jumlah item yang ada didalam kegiatan, yang didapat dari jumlah item dibagi jumlah semua kegiatan di kali seratus persen. Tabel 2. adalah item data yang memenuhi support minimal, nilai support minimal sama dengan 20 persen (20\%). Seperti yang terlihat pada tabel 2. berikut ini:

Tabel 2. Kegiatan Kombinasi Satu Itemset yang memenuhi minimum support

\begin{tabular}{|l|c|c|}
\hline \multicolumn{1}{|c|}{ Kegiatan } & Support & Support (\%) \\
\hline Memberikan surat pemberitahuan penunggak pajak & 3 & 21,43 \\
\hline Koordinasi ke vendor untuk pajak reklame & 3 & 21,43 \\
\hline Sosialisasi ke wajib pajak reklame & 5 & 21,43 \\
\hline $\begin{array}{l}\text { Memonitor laporan bulanan ke wajib pajak untuk pajak } \\
\text { Perhotelan }\end{array}$ & 5 & 35,71 \\
\hline Memonitor laporan bulanan ke WP untuk pajak Restoran & 6 & 42,85 \\
\hline $\begin{array}{l}\text { Memverifikasi ketidak cocokan data di kantor dinas dan } \\
\text { data dilapangan }\end{array}$ & 5 & 35,71 \\
\hline $\begin{array}{l}\text { Pengawasan langsung di lokasi usaha WP jika terdapat } \\
\text { ketidak sesuaian laporan dari data di lokasi }\end{array}$ & 5 & 35,71 \\
\hline $\begin{array}{l}\text { kegiatan dilakukan oleh 51 orang PNS dan 121 orang } \\
\text { Pegawai tidak tetap }\end{array}$ & 6 & 42,85 \\
\hline Rekapitulasi absensi (95\%) & 3 & 21,43 \\
\hline Tingkat kesadaran masyarakat (75\%) & 3 & 21,43 \\
\hline
\end{tabular}

Tabel 2. diatas merupakan data item jenis kegiatan yang memenuhi support minimal. Dimana data diatas akan digunakan untuk membentuk pola kombinasi dua item mulai dari pembentukan pola kombinasi dua itemsets, sampai pada pembentukan pola kombinasi lima itemsets.

\subsection{Pembentukan Pola Kombinasi Dua Itemsets}

Pembentukan pola frekuensi dua itemsets, dibentuk dari items-items jenis kegiatan yang memenuhi support minimal yaitu dengan cara mengkombinasi semua items kedalam pola dua kombinasi. 
Dengan ditentukannya minimum support sama dengan 20 persen (20\%), maka data yang memenuhi minimum support akan dijelaskan pada tabel berikut ini:

Tabel 3. Pola Kombinasi Dua Itemsets yang Memenuhi Minimum Support

\begin{tabular}{|c|c|c|}
\hline Kegiatan & Support & Support(\%) \\
\hline $\begin{array}{l}\text { Koordinasi ke vendor untuk pajak reklame, Sosialisasi ke } \\
\text { wajib pajak reklame }\end{array}$ & 3 & 21,42 \\
\hline $\begin{array}{l}\text { Koordinasi ke vendor untuk pajak reklame, Memonitor } \\
\text { laporan bulanan ke wajib pajak untuk pajak Perhotelan }\end{array}$ & 3 & 21,42 \\
\hline $\begin{array}{l}\text { Memonitor laporan bulanan ke wajib pajak untuk pajak } \\
\text { Perhotelan, Sosialisasi ke wajib pajak reklame. }\end{array}$ & 4 & 28,57 \\
\hline $\begin{array}{l}\text { Sosialisasi ke wajib pajak reklame, Memonitor laporan } \\
\text { bulanan ke wajib pajak untuk pajak Perhotelan. }\end{array}$ & 4 & 28,57 \\
\hline $\begin{array}{l}\text { Memonitor laporan bulanan ke wajib pajak untuk pajak } \\
\text { Perhotelan, Memonitor laporan bulanan ke WP untuk pajak } \\
\text { Restoran }\end{array}$ & 3 & 21.42 \\
\hline $\begin{array}{l}\text { Memverifikasi ketidak cocokan data di kantor dinas dan data } \\
\text { dilapangan, Memonitor laporan bulanan ke WP untuk pajak } \\
\text { Restoran. }\end{array}$ & 4 & 28,57 \\
\hline $\begin{array}{l}\text { Pengawasan langsung di lokasi usaha WP jika terdapat } \\
\text { ketidak sesuaian laporan dari data di lokasi, kegiatan } \\
\text { dilakukan oleh } 51 \text { orang PNS dan } 121 \text { orang Pegawai tidak } \\
\text { tetap }\end{array}$ & 4 & 28,57 \\
\hline $\begin{array}{l}\text { Rekapitulasi absensi (95\%), Pengawasan langsung di lokasi } \\
\text { usaha WP jika terdapat ketidak sesuaian laporan dari data di } \\
\text { lokasi. }\end{array}$ & 3 & 21,42 \\
\hline $\begin{array}{l}\text { Tingkat kesadaran masyarakat (75\%), Pengawasan langsung } \\
\text { di lokasi usaha WP jika terdapat ketidak sesuaian laporan } \\
\text { dari data di lokasi }\end{array}$ & 3 & 21,42 \\
\hline $\begin{array}{l}\text { Rekapitulasi absensi (95\%), kegiatan dilakukan oleh } 51 \\
\text { orang PNS dan } 121 \text { orang Pegawai tidak tetap. }\end{array}$ & 3 & 21,42 \\
\hline $\begin{array}{l}\text { Tingkat kesadaran masyarakat ( } 75 \%) \text {, kegiatan dilakukan } \\
\text { oleh } 51 \text { orang PNS dan } 121 \text { orang Pegawai tidak tetap. }\end{array}$ & 3 & 21,42 \\
\hline
\end{tabular}

\subsection{Pembentukan Association Rules dua itemset}

Setelah semua pola kombinasi dua itemset frekuensi tinggi ditemukan, baru dicari association rules yang memenuhi syarat minumum nilai confidence, dengan menghitung confidence aturan asosiasi A ke B. Nilai confidence dari aturan $\mathrm{A}$ ke $\mathrm{B}$ diperoleh dengan rumus = Jumlah setiap transaksi yang mengandung item $\mathrm{A}$ dan item $\mathrm{B}$ dibagi dengan jumlah transaksi yang mengandung $A$ dikali seratus persen. Contoh untuk pola kombinasi 2 itemset $(\mathrm{AB})$ Memberikan surat pemberitahuan penunggak pajak dan Sosialisasi ke wajib pajak reklame $=2$, nilai support $(\mathrm{A})$ Memberikan surat pemberitahuan penunggak pajak $=3$, untuk mencari nilai confidencenya : 2 / 3 x 100\% $=66,6 \%$.

Sedangkan untuk nilai lift yang merupakan sebuah angka rasio yang menunjukkan berapa banyak kemungkinan menemukan sebuah atribut muncul bersama dengan atribut lainnya dibandingkan dengan seluruh 
kejadian adanya atribut yang terpenuhi. Dan lift sendiri menunjukkan adanya tingkat kekuatan rule atas kejadian acak dari antecedent dan consequence berdasarkan pada supportnya masing masing, untuk lift sendiri didefenisikan sebagai berikut : Lift = Confidence $/$ bencmark Confidence . Dimana Bencmark Confidence $=($ Jumlah transaksi memiliki item consequent $) /($ Total jumlah transaksi). Jika nilai lift rasio lebih besar dari 1 maka hal tersebut menunjukkan adanya manfaat dari aturan tersebut, semakin besar nilai lift rasio maka semakin besar pula kekuatan asosiasi.

Contoh untuk menentukan nilai lift dari pola kombinasi 2 itemset (AB) Memberikan surat pemberitahuan penunggak pajak dan Sosialisasi ke wajib pajak reklame. Untuk nilai Bencmark Confidence : support Sosialisasi ke wajib pajak reklame (item consequent $)=3 / 14$ jumlah transaksi $=0,2142$. Maka untuk nilai lift $=$ Confidence $/$ bencmark Confidence atau lift : 66,6 / 0,2142 = 310,9 . Dengan menetapkan nilai minumum confidence sebesar 90 persen (90\%), dan minumum support 20 persen (20\%) maka rules interesting yang dihasilkan adalah seperti pada tabel 4 . berikut ini:

Tabel 4. Association Rules dari Kombinasi Dua Itemset yang Memenuhi Minimum Confidence dari tabel 3.

\begin{tabular}{|l|c|c|c|c|}
\hline \multicolumn{1}{|c|}{ Rules } & $\begin{array}{c}\text { Support } \\
\text { (itemsets) }\end{array}$ & Lift & $\begin{array}{c}\text { Support } \\
\text { (\%) }\end{array}$ & $\begin{array}{c}\text { Confi dence } \\
\text { (\%) }\end{array}$ \\
\hline $\begin{array}{l}\text { Jika Koordinasi ke vendor untuk } \\
\text { pajak reklame maka juga Memonitor } \\
\text { laporan bulanan ke wajib pajak } \\
\text { untuk pajak Perhotelan }\end{array}$ & 3 & 2,800 & 21,429 & 100 \\
\hline $\begin{array}{l}\text { Jika Tingkat kesadaran masyarakat } \\
\text { (75\%) maka juga Pengawasan } \\
\text { langsung di lokasi usaha WP jika } \\
\text { terdapat ketidak sesuaian laporan } \\
\text { dari data di lokasi }\end{array}$ & 3 & 2,80 & 21,429 & 100 \\
\hline $\begin{array}{l}\text { Jika Rekapitulasi absensi (95\%) } \\
\text { maka juga Pengawasan langsung di } \\
\text { lokasi usaha WP jika terdapat } \\
\text { ketidak sesuaian laporan dari data di } \\
\text { lokasi. }\end{array}$ & 3 & 2,80 & 21,429 & 100 \\
\hline $\begin{array}{l}\text { Jika Koordinasi ke vendor untuk } \\
\text { pajak reklame maka juga Sosialisasi } \\
\text { ke wajib pajak reklame }\end{array}$ & 3 & 2,800 & 21,429 & 100 \\
\hline $\begin{array}{l}\text { Jika Tingkat kesadaran masyarakat } \\
\text { (75\%) maka juga kegiatan dilakukan } \\
\text { oleh 51 orang PNS dan 121 orang } \\
\text { Pegawai tidak tetap. }\end{array}$ & 3 & 2,33 & 21,429 & 100 \\
\hline $\begin{array}{l}\text { Jika Rekapitulasi absensi (95\%) } \\
\text { maka juga kegiatan dilakukan oleh } \\
\text { 51 orang PNS dan 121 orang } \\
\text { Pegawai tidak tetap. }\end{array}$ & 3 & 2,80 & 21,429 & 100 \\
\hline
\end{tabular}


Untuk rule kombinasi dua itemset yang memenuhi nilai minimum confidence merupakan rules interesting yang dihasilkan akan dijabarkan sebagai berikut :

a. Jika Koordinasi ke vendor untuk pajak reklame maka juga Memonitor laporan bulanan ke wajib pajak untuk pajak Perhotelan

b. Jika Tingkat kesadaran masyarakat (75\%) maka juga Pengawasan langsung di lokasi usaha WP jika terdapat ketidak sesuaian laporan dari data di lokasi.

c. Jika Rekapitulasi absensi (95\%) maka juga Pengawasan langsung di lokasi usaha WP jika terdapat ketidak sesuaian laporan dari data di lokasi.

d. Jika Koordinasi ke vendor untuk pajak reklame maka juga Sosialisasi ke wajib pajak reklame.

e. Jika Tingkat kesadaran masyarakat (75\%) maka juga kegiatan dilakukan oleh 51 orang PNS dan 121 orang Pegawai tidak tetap.

f. Jika Rekapitulasi absensi (95\%) maka juga kegiatan dilakukan oleh 51 orang PNS dan 121 orang Pegawai tidak tetap.

\section{HASIL DAN PEMBAHASAN}

Pada tahap ini akan di lakukan implementasi dan pengujian, tahapan ini di lakukan setelah analisis dan pembentukan assosition rule selesai kemudian diimplementasikan pada aplikasi. Data yang didapat dari Badan Pendapatan Kab. Deli Serdang adalah data Kegiatan yang dilakukan selama 3 bulan yaitu dari bulan Maret, April dan Mei 2018 serta data pencapain target pajak dari bulan Januari sampai Mei 2018. Sedangkan untuk aplikasi pengujian yang akan digunakan adalah alikasi Tanagra versi 1.4.50.

\subsection{Tabular Data}

Dikarenakan aplikasi yang di gunakan berupa aplikasi yang menggunakan Mocrosoft Office Excel 2007, maka format yang digunakan berupu tabular data. Tabular data merupakan data yang tersaji dalam bentuk 1 dan 0 atau biasa dikatakan dengan format dalam bentuk biner. Data transaksi penjualan alat kesehatan harus dikonversi kedalam bentuk format tabular data tersebut. Proses konversi data penjualan alat kesehatan kebentuk tabular data dengan cara sebagai berikut:

a. Untuk tanggal dalam bentuk mingguan disusun vertikal kebawah diurutkan dari minggu pertama awal bulan.

b. Untuk nama atau jenis item atau jenis kegiatan disusun horizontal dari kiri kekanan diurutkan sesuai abjad, jenis item kegiatan dijadikan sebagai attribute.

c. Setelah tanggal dan jenis item disusun sehingga membentuk sebuah tabel kemudian dicari titik temu antara tanggal dan jenis item kegiatan yang dilakukan.

Jika ditemukan tannggal dan jenis kegiatan maka menjadi biner 1, namun jika tidak ditemukan tanggal dan jenis kegiatan tersebut maka akan menjadi biner 0, langkah tersebut dilakukan berulang sampai semua tanggal 
dan jenis item kegiatan selesai urutannya di tabel, Berikut adalah jenis kegiaatan yang akan dimasukkan dalam bentuk tabular data yang sudah di urutkan sesuai abjad. Untuk dapat diproses di aplikasi data mining Tanagra setiap kegiatan digantikan dengan pengkodean agar data tabular bisa di konversi dan di proses di aplikasi data mining Tanagra. Untuk pengkodean kegiatan akan di jelaskan pada tabel berikut :

Tabel 5. tabel jenis kegiatan yang sudah diberikan Pengkodean

\begin{tabular}{|c|l|l|}
\hline No & \multicolumn{1}{|c|}{ Jenis Kegiatan } & Kode yang digunakan \\
\hline 1 & $\begin{array}{l}\text { Bekerjasama dengan Satpol PP menindak wajib pajak yang } \\
\text { tidak memiliki kesadaran setelah mendapat SP3 }\end{array}$ & Kegiatan 1 \\
\hline 2 & $\begin{array}{l}\text { Kantor Dinas mengeluarkan surat keterangan ke KUPTD } \\
\text { Wajib Pajak yang sudah jatuh tempo maupun yang baru }\end{array}$ & Kegiatan 2 \\
\hline 3 & $\begin{array}{l}\text { Kegiatan dilakukan oleh 51 orang PNS dan 121 orang } \\
\text { Pegawai tidak tetap }\end{array}$ & Kegiatan 3 \\
\hline 4 & Koordinasi ke vendor untuk pajak reklame & Kegiatan 4 \\
\hline 5 & Memberikan surat pemberitahuan penunggak pajak & Kegiatan 5 \\
\hline 6 & $\begin{array}{l}\text { Membuat surat peringatan 1 sampai 3 ke Wajib Pajak yang } \\
\text { membandel }\end{array}$ & Kegiatan 6 \\
\hline 7 & $\begin{array}{l}\text { Memonitor laporan bulanan ke wajib pajak untuk pajak } \\
\text { Perhotelan }\end{array}$ & Kegiatan 7 \\
\hline 8 & Memonitor laporan bulanan ke WP untuk pajak Restoran & Kegiatan 8 \\
\hline 9 & $\begin{array}{l}\text { Memverifikasi ketidak cocokan data di kantor dinas dan } \\
\text { data dilapangan }\end{array}$ & Kegiatan 9 \\
\hline 10 & $\begin{array}{l}\text { Pegawai atau Petugas mengantarkan surat keterlambatan } \\
\text { ke wajib pajak }\end{array}$ & Kegiatan 10 \\
\hline 11 & $\begin{array}{l}\text { Pengawasan langsung di lokasi usaha WP jika terdapat } \\
\text { ketidak sesuaian laporan dari data di lokasi }\end{array}$ & Kegiatan 11 \\
\hline 12 & Rapat Evaluasi PAD & Kegiatan 12 \\
\hline 13 & Rekapitulasi absensi (95\%) & Kegiatan 13 \\
\hline 14 & Sosialisasi ke wajib pajak reklame & Kegiatan 14 \\
\hline 15 & Tingkat kesadaran masyarakat (65\%) & Kegiatan 15 \\
\hline 16 & Tingkat kesadaran masyarakat (70\%) & Kegiatan 16 \\
\hline 17 & Tingkat kesadaran masyarakat (75\%) & Kegiatan 17 \\
\hline
\end{tabular}

\subsection{PengujianPengujian Pola Kombinasi Dua Itemset}

Selanjutnya untuk menentukan pola kombinasi dua itemset dilakukan dengan cara menentukan nilai parameternya untuk nilai minimum lenght di naikkan menjadi 2. Sedangkan untuk nilai minimum support masih sama 20 $\%$ maximum support $100 \%$, minimum confidence $90 \%$, minimum lenght 2 dan maximum lenght 2 . Tampilan penentuan parameter pola kombinasi tiga itemset seperti pada gambar 2 berikut : 


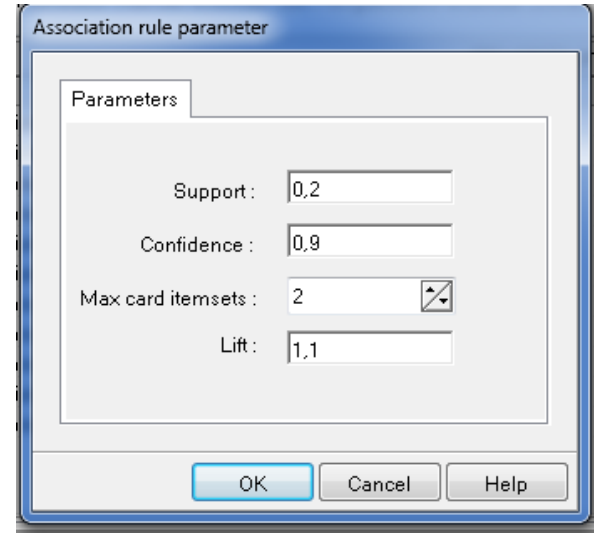

Gambar 2. Parameters Pola Kombinasi Dua Itemset

Setelah nilai parameternya ditentukan kemudian klik ok dan kemudian klik kanan di menu frequent itemset 1 di jendela sebelah kiri dan pilih execute. Sedangkan untuk melihat hasil dari penentuan pola kombinasi itemset caranya dengan mengklik kanan pada menu frequent itemset 1 di jendela kiri lalu pilih view. Hasil dari penentuan pola kombinasi itemset akan di jelaskan pada gambar 3. berikut :

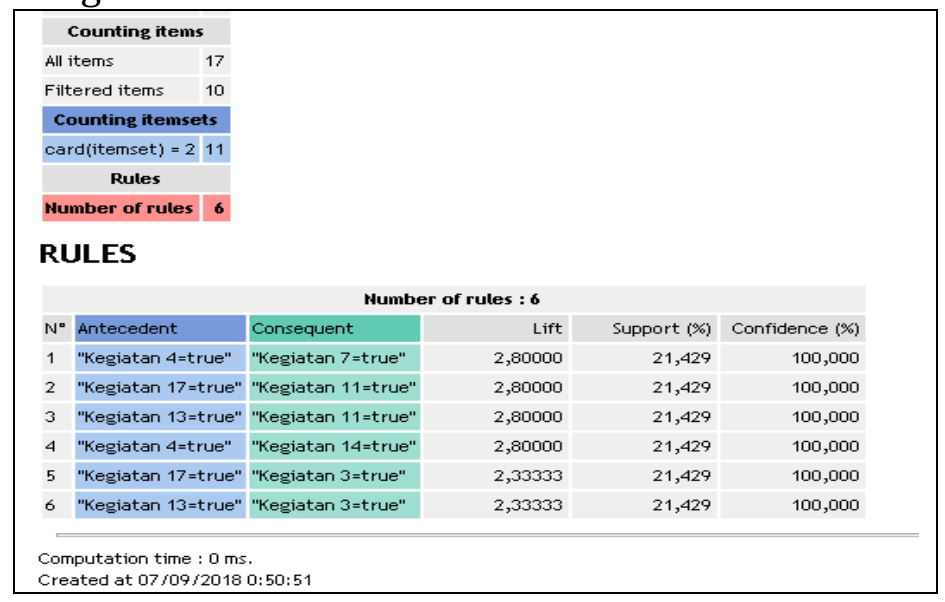

Gambar 3. Hasil Pengujian Frequent 2 Itemset

Gambar 3 merupakan gambar tampilan hasil dari Frequent Itemset yang berisi keterangan 2 itemset yang memenuhi minimum support $20 \%$ dan minimum confidence $90 \%$. Dari gambar 3 di atas juga menampilkan dua atribut yaitu atribut description dan support. Description menggambarkan jenis item dan pola kombinasi dua itemset, sedangkan di atribut support menunjukkan persentase kemunculan item maupun pola kombinasi 2 itemset dalam semua kegiatan yang dilakukan.

\section{SIMPULAN}

Pengujian dengan rule dua kombinasi menghasilkan 6 rule, sistem menampilkan semua kombinasi dua itemset. Hasil kombinasi dari 2 itemset 
yang memenuhi nilai minimum support $20 \%$ dan nilai minimal confidence $90 \%$ ada 6 rule interesting, di antaranya adalah sebagai berikut :

a. Jika Koordinasi ke vendor untuk pajak reklame maka juga Memonitor laporan bulanan ke wajib pajak untuk pajak Perhotelan dengan nilai lift $=$ 2,800 dan nilai support $=21,429$ nilai confidence $=100$

b. Jika Tingkat kesadaran masyarakat (75\%) maka juga Pengawasan langsung di lokasi usaha WP jika terdapat ketidak sesuaian laporan dari data di lokasi dengan nilai lift $=2,800$ dan nilai support $=21,429$ nilai confidence $=100$

c. Jika Rekapitulasi absensi (95\%) maka juga Pengawasan langsung di lokasi usaha WP jika terdapat ketidak sesuaian laporan dari data di lokasi dengan nilai lift $=2,800$ dan nilai support $=21,429$ nilai confidence $=100$

d. Jika Koordinasi ke vendor untuk pajak reklame maka juga Sosialisasi ke wajib pajak reklame dengan nilai lift $=2,800$ dan nilai support $=21,429$ nilai confidence $=100$

e. Jika Tingkat kesadaran masyarakat (75\%) maka juga kegiatan dilakukan oleh 51 orang PNS dan 121 orang Pegawai tidak tetap dengan nilai lift $=$ 2,800 dan nilai support $=21,429$ nilai confidence $=100$

f. Jika Rekapitulasi absensi (95\%) maka juga kegiatan dilakukan oleh 51 orang PNS dan 121 orang Pegawai tidak tetap dengan nilai lift $=2,800$ dan nilai support $=21,429$ nilai confidence $=100$

Dengan didapatkannya aturan asosiasi di atas maka para pengambil keputusan dapat merencanakan ataupun merekomendasikan kombinasi beberapa kegiatan untuk tetap mempertahankan kegiatan yang interesting yang didapat dari hasil pengujian menggunakan teknik association rule dengan metode apriori.

\section{DAFTAR PUSTAKA}

[1] Jnanamurthy et al, (2013). "Discovery of Maximal Frequent Item Sets using Subset Creation". International Journal of Data Mining \& Knowledge Management Process (IJDKP) Vol.3.

[2] Sutrisno et al, (2013). "Penerapan Data Mining Pada Penjualan menggunakan Metode Clustering Study Kasus PT. Indomarco Palembang". Jurnal Ilmiah Teknik Informatika Ilmu Komputer Vol.x No.x.

[3] Gunadi G et. al (2011)."Penerapan Metode Data Mining Menggunakan Market Basket Analysis Terhadap Data Penjualan Produk Buku dengan Menggunakan Algoritma Apriori dan Frequent Pattern Growth (FPGrowth)." Jurnal Telematika Mkom. Vol.4 No.1. 119-122.

[4] Elmande Y et. al (2012). "Pemilihan Criteria Splitting dalam Algoritma Iterative Dichotomiser 3 (ID3) untuk Penentuan Kualitas Beras : Studi Kasus pada Perum Bulog Divre Lampung." Jurnal Telematika Mkom. Vol.4. 74-75. 